\title{
The Impact of Change Management on the Application Enterprise Resource Planning System (ERP) Effectiveness: Field Study in Jordan Bromine Company
}

\author{
Hisham Othman Al-Mobaideen \\ Assistant Professor \\ Department of Management Information Systems \\ Mu'tah University/ Jordan \\ E-mail: h_mobaideen@yahoo.com h.mobaideen@mutah.edu.jo
}

Received: August 14, 2014

doi:10.5296/jmr.v6i4.6137
Accepted: Sep. 21, 2014

Published: October 1, 2014

URL: http://dx.doi.org/10.5296/jmr.v6i4.6137

\begin{abstract}
This study aimed to identify the impact of change management on the application of Enterprise resource planning system (ERP) effectiveness in the Jordan Bromine company, to achieve the objective of the study a questionnaire that consisted of (28) paragraph was built, and its validity and consistency were verified, the study was applied on a sample of (125) employees in the company, and after analyzing data the results of the study have indicated that the degree of rehabilitation and efficiency of staff were high with (4.69) arithmetic mean and (42\%) standard deviation. This may be attributed to staff members' awareness of the importance of training as it helps to accept the new regulations and their application. The degree of personnel awareness of the importance of the application of Enterprise resource planning system (ERP) was high with (4.57) arithmetic mean, (45\%) standard deviation, whereas the degree of consensus expectations of staff with the practical application of the Enterprise resource planning system (ERP) was high with (4.38) arithmetic mean, (54\%) standard deviation. The results indicated the effective application of the Enterprise resource planning system (ERP) is significantly affected by staff training and spreading knowledge between staff.
\end{abstract}

Keywords: Management, Application, Enterprise, Resource, Planning system, Effectiveness, Company 


\section{Introduction}

Understanding the importance of the process of change is a prerequisite and a necessity to community, where change is a feature of the times and is no longer a luxury or some kind of urbanization but became inevitable in the age of economic openness and information explosion and marginalization of change means to melt and fade (Scott and Jeff, 2005).

Change management can be a solution to mitigate and reduce the risks faced by the company and to increase its effectiveness and success and to reduce resistance of positive change by communicating with employees and increase their knowledge about the project. So, organizations need a new management capable of leadership, creativity and innovation and to deal with variables more efficiently.

Enterprise resource planning system (ERP) is an integrated set of software that provides regulatory activities such as manufacturing, finance ,accounting, sales and marketing, and human resources, and that this system helps various parts of the Organization to share data and knowledge, reduce costs, improve management process. This system faces many difficulties during its application because of personnel resistance.

\section{The study problem}

Revolutions in the field of knowledge, communication and technology moreover the complications in the business environment, growing volume of business, and growing interdependence with many political, economic and cultural change of concepts, tools and methods used, entailed new standards for efficiency and effectiveness in the development of information systems (Al-taie, 1995).

The problem of the study is to identify the extent of change management effect on the effectiveness of Enterprise resource planning system (ERP) in Jordan Bromine company, so the problem of the study questions may by presented by the following three questions:-

1. What is the extent of rehabilitation and efficiency of the staff on using Enterprise resource planning system (ERP) in Jordan Bromine Company?

2. What is the extent of employee understanding and awareness of the importance of the application of Enterprise resource planning system (ERP) in the Jordan Bromine Company?

3. What is the extent of compatibility predictions with the actual application of the Enterprise resource planning system (ERP) in the Jordan Bromine Company?

\section{The importance of the study}

The importance of this study emerges from the lack of studies in the area of internal capacity-building for staff in the industrial sector in Jordan and in particular. Such studies contribute actively to the dissemination of knowledge among the staff of the target companies as a positive impact on the transition process of the change process, as is the case in the Jordan Bromine Company. 


\section{Macrothink}

Journal of Management Research

ISSN 1941-899X

2014, Vol. 6, No. 4

\section{The study objectives}

1. To identify the role of change management in the effective application of the Enterprise resource planning system (ERP) in the Jordan Bromine Company.

2. To identify the relationship of change management and Enterprise resource planning and concepts associated with each one.

\section{The study model}

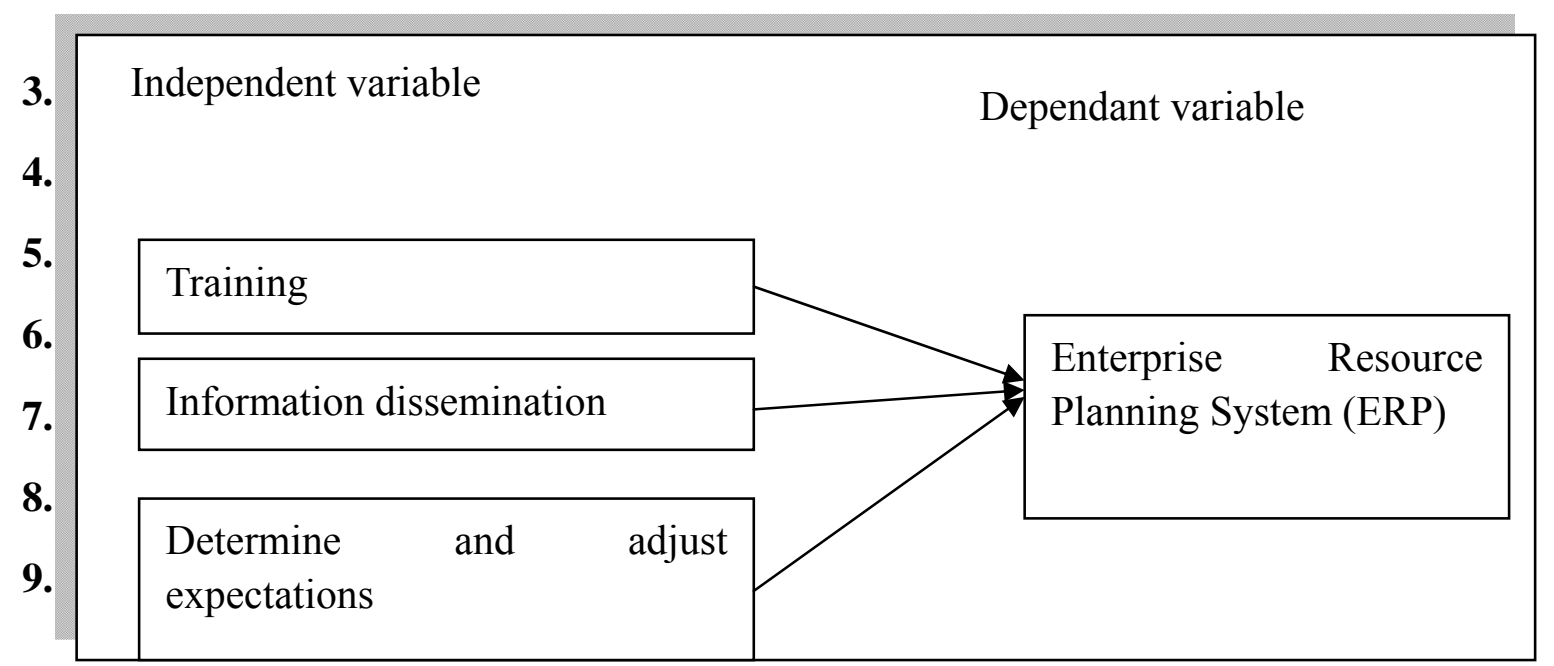

\section{The study hypotheses}

\section{The main hypothesis of the study}

- There is no statistically significant effect of change management application according to (training, dissemination of knowledge, expectations identification and adjustment) dimensions, on the effective application of the system.

The main hypothesis may be divided into 3 sub hypotheses:

\section{The First Hypothesis}

- There is no statistically significant impact of staff training on the effective application of the Enterprise resource planning system (ERP).

\section{The Second Hypothesis}

- There is no statistically significant effect of disseminating knowledge between staff on the effective application of the Enterprise resource planning system (ERP).

\section{The Third Hypothesis}

- There is no statistically significant impact of ne expectations identification and adjustment on the effective application of the Enterprise resource planning system (ERP). 


\section{Procedural definitions}

1. Change managing: a dynamic parallelism between two forces working in opposite directions in the field of physical, social and psychological work with one group driving force while the adverse force restricted group as a result of the interaction of two forces with each the organization reach a State of balance, called the current situation (Alserafi, 2008).

2. Training: a way for an individual to exercise and exploit the outcomes of education for practical life while education care for knowledge as a qualification for entry into working life (Yaghi, 2003).

3. Knowledge management: knowledge management is a term associated with processes or stages for creating, deploying, testing, and use of knowledge for useful purposes "(Wikipedia).

4. Expectations identification and adjustment: the company's ability to adapt and cope with changes in the external environment, and its ability to detect and exploit opportunities and avoid threats through its capabilities and internal sources

\section{Literature review and previous studies}

Change management is a dynamic equivalent between two forces working in opposite directions in the physical, social and psychological field of work with one group driving force while the adverse force restricted group as a result of the interaction of two forces with each other the organization reach a state of balance, called the current situation (Alserafi, 2008). (Al-Titi, 2010) defined change as the process used by the Organization to design, implement and evaluate of appropriate initiatives to deal with the requirements imposed by the external environment where change management requires wise leadership capable of development, prosperity and progress depending on the circumstances surrounding of the organization. (Abodie, 2006) has clarified that managing change includes moving establishment from its current state to another desirable mode during a transition period.

Change aims to increase the Organization's ability to cope and adapt to their environment and improve their ability to survive and grow, and the increase Organization's ability to cooperation among the various specialized groups in order to achieve the overall objectives of the organization. Also change helps the Organization to solve problems faced by providing information on the various processes and outcomes (Alserafi, 2008).

There are four levels of change: knowledge as a first level where the idea is introduced. The second level is the direction and the assertion of the conviction to change until the individual have a positive guidance and enthusiasm for this change. The third level is related to the individual behavior, the behavior that necessity and conviction to change and determination to achieve it. The collective behavior is the fourth level, where the Group espouses the idea of change and demands it and work according to and then the change becomes a collective behavior (Alserafi, 2008).

Change is an ongoing process. It is a continuous process and doesn't happen once and then stop. Change is a planned work that is based on the discovery of the need for change, which usually occurs as a result of problems in the current system or changes in circumstances or is expected 
to occur in circumstances that would require a change of plan. Change is an administrative responsibility, in general change is preferably happened with the participation of administration men with the employees and the administration could use the help of a specialized department in the organization or the help of an outside change consultant and in all cases organized change still the responsibility of administration, and it success needs the participation of the employees with the administration to help in introducing it to the organization. Change is based on the concept of open system which means that change happened in the organization as a result of influence of outside circumstances on the organization. The change also intended to improve the organizational effectiveness by increasing organization's ability to achieve its goals and its ability to survive and develop in the changing circumstances in the organization. In addition to this for change to happen it rely on the participation of the employees with the administration so there is no perfect one system to make change because the way of change and how to implement it can differ from one organization to another depending on its circumstances (Hareem, 2006). The change models represent the outline that contains variables or factors relevant to change, among the major forms is Curt Lyons model that has received considerable attention and widely acceptance and suggests that any schema change and conscious process includes three phases: 1-(Unfreezing) which involves the exclusion and cancellation of attitudes, values, customs and current practices and behaviors of the individual to create a sense of having something new.2- (Moving) which means that there is a real change and adjustment in this phase in duties tasks performance technology or organizational structure. 3- (Refreezing) which means that what the individual has learned from ideas skills and new directions in a change phase has integrated in actual practice.

However, reactions from the affected individuals with the change may be characterized by disbelief or resistance and restrict contributions, and requires an effort of organizations and managers in planning the change and convince staff of it (Abood, 2006).

Training is a way for the individual to practice work and use the outcomes of education for practical life while education care with knowledge as a qualification for entry into working life (Yaghi, Mohammad., 2003). The training focuses on behavioral aspects and raising individual and collective skills (Aboode, change management and development, 2006).

One of the Organization's assets is to (Know How) and (Know Why), and one of the most important assets of the organization is the physical assets that have the ability to convert technical research phase to the implementation phase for the production of goods and services (Krasnh;Al-Kalili,2009).

Enterprise resource planning system (ERP) is based on collecting information and processes for the organization in one system contains multiple systems and devices, all in a single database. Recent Enterprise resource planning system (ERP) can meet a wide range of jobs and like HR, SCM, CRM, accounting, inventory management, selling and buying, production, and this is what is called ERP system (Alidwani, 2001). ERP is an industrial term supports multiple applications and systems that uses a common database, and implementation of the Enterprise resource planning system (ERP) can also contain the analysis of the processes within the 
system, training of personnel and procedures used at work (Al Nafjan, and Almodmaj, 2005). ERP may be very rigid and non-profitable for certain organizations that are either new or want to move in a new direction in the near future (Al Bali, 2011). ERP implementation within the Organization is examined regularly by project team for any disorder or detecting any error. (Alshamlan \&Almdmth, 2011).

Information systems of different types have very high investment and maintenance costs, so attention of organizations has begun to have an effective management information system to achieve what is required. Effectiveness is the degree to which the objectives are achieved so that the degree of effectiveness of the system depends on how much goals they achieved and the better output achieve from other systems $(\mathrm{OZ}, 2000)$ and is known as the range at which the goals has been achieved (Daft,2001).

The effectiveness of management information system has been defined as "the extent to which management information system participate in achieving organizational goals"(Hamiltion \& Chervancey, 1981). Kim (1989) adapted the previous definition by saying" as the organizational goals that in management information system participate in its achievement can be expressed using idioms like the efficiency of decision making, productivity, relationships among individuals, work satisfaction...etc, so we can define the efficiency of management information system as a participation in management information system in completing and achieving the efficiency of decision making, productivity, relationships among individuals, work satisfaction”. Burns \& Madey (2001) distinguish between the definitions of the efficiency of information management system according to its concept according to the organization and the beneficiary. Many companies began looking to the management information system as a tool for achieving competitive advantage in front of its competitor (Hicks, 1973).

Albali (2011) studied the effective change management strategies, Enterprise resource planning system (ERP) in Saudi national Robian company aiming to determine the effectiveness of strategies for change management in Enterprise resource planning system (ERP). The study has showed that ERP systems provide enormous benefits to the organizations in efficiency, productivity, quality management, reduce costs and take quick change management strategies that include training communications and incentives.

Al-Shamlan and Al medmth (2011) have studied change management strategies and implementation of successful Enterprise resource planning system (ERP) applied to Madar company, this study discusses successful strategies for managing change and operations concluding that there should be a system application change management and operational activities, such as training and communications. Almuriat (2008) proposed an educational strategy for change management in the south of the Hashemite Kingdom of Jordan territory. The study found that there are requirements for building the proposed change management strategy represented by identifying the goals and quality standards and the proposed education strategy for managing change.

Harem study (2006) aimed to identify the nature of the impact of the use of companies operating in the chemical industries sector in Jordan for the change management process (melting, change, and freezing) in resistance to change. The study found that there is an 
acceptable application level to stages of change management by the companies that mediate resistance to change and lack of moral effect of melting and freezing resistance of workers for reasons of substance.

AlFarisi (2006) studied the impact of human resource management functions in achieving organizational change in central ministries in the Sultanate of Oman. The study concluded that there is a statistically significant impact of human resource management functions in achieving organizational change in the ministries and that there is no statistically significant difference for human resources management functions and change attributable to the demographic characteristics and functional variables.

Sabag (2005) found that the access of technology to the information environment has changed the method that information organization serves their customers, all indications suggest that this change continues and every time information Organization has established new service information, the role of information is going to change dramatically to keep pace with the changes that it will bring a new service in an organization.

Algilani (2005) identified the role of change management in the Ministry of education of the Sultanate of Oman from perspective of employees. It was found is that there are different estimates about the areas of change management in the Ministry of education in the Sultanate of Oman between high and medium, where information technology came in the first place followed by goals, organizational structures, human resource development and leadership and decision-making occupied the fourth place and the partnership with the local community was in the fifth level.

Al Nafjan and almodmth (2005) studied the impact of change management on the Enterprise resource planning system (ERP) identifying the reasons for the individuals' resistance of change process within the Organization, and suggested practical strategies for minimizing resistance if not overcome them. The study concluded that using Enterprise resource planning system (ERP) improves the efficiency and effectiveness of the IT infrastructure, and enables integration of business worldwide.

Study of Wieder \& Booth (2006) aimed to provide further clarifications on the Enterprise resource planning system (ERP) and their impact on organizational performance. The study conducted a survey to collect data on many aspects of organizational performance in companies that adopted ERP systems and found that the financial key performance indicators were used to measure the overall performance of the company and the supply chain operations reference model to activate performance in business processes.

Nicolaou \& Bhattachary (2006) identified the long-term implications and impact of the performance management system and resource planning demonstrating that the Enterprise resource planning system (ERP) may result in performance gains or losses as a result of organizational changes that began after the first system, This study examines the changes to the Enterprise resource planning system (ERP), which in turn affect the time frame after the implementation of the system and thus affect the ability of the company in the long term to achieve ideal performance. 


\section{Methodology of the study}

The study population consists of 400 employees of Jordan Bromine Company staff. Intended sample was used which include all individuals working on the layout system in Jordan Bromine Company sources, the 140 copies of the questionnaire was distributed which is equivalent to (35\%) of the study population, 125copies were recovered and valid for purposes of scientific research.

Table 1. Distribution of sample members by gender

\begin{tabular}{|l|l|l|}
\hline Gender & Number & Percentage \\
\hline Male & 118 & 94.4 \\
\hline Female & 7 & 5.6 \\
\hline Total & 125 & 100 \\
\hline
\end{tabular}

It can be seen from the table (1) above that the proportion of males in the sample is more than females with (94.4) for male and (5.6) for females.

Table 2. The distribution of the sample members by age

\begin{tabular}{|l|l|l|}
\hline Age & Number & Percentage \\
\hline 25 years less & 12 & 9.6 \\
\hline $26-35$ years & 50 & 40 \\
\hline $36-45$ years & 56 & 44.8 \\
\hline More than 45 & 7 & 5.6 \\
\hline Total & $125 \%$ & 100 \\
\hline
\end{tabular}

It can be seen from the table above that (36-45) had the highest percentage $(44.8 \%)$ of the sample while (over 45 years) ranked last (5.6\%).

Table 3. Distribution of sample members by qualification

\begin{tabular}{|l|l|l|}
\hline Qualification & Number & Percentage \\
\hline Secondary or less & 28 & 22.4 \\
\hline Diploma & 54 & 43.2 \\
\hline Bachelor degree & 37 & 26.6 \\
\hline Higher studies & 6 & 4.8 \\
\hline total & 125 & $100 \%$ \\
\hline
\end{tabular}

It can be seen from the table above that the staff with diploma is the highest (43.2\%), While the proportion of higher degree ranked last with (4.8\%) of the sample study.

Table 4. The distribution of the sample members by work experience

\begin{tabular}{|l|l|l|}
\hline Experience in the work & Number & Percentage \\
\hline 5 years or less & 16 & 12.8 \\
\hline $6-10$ & 39 & 31.2 \\
\hline $15-11$ & 43 & 34.4 \\
\hline 16 and more & 27 & 21.6 \\
\hline Total & 125 & $100 \%$ \\
\hline
\end{tabular}


It can be seen from the table above that percentage of staff expertise (11-15 years) had the highest percentage (34.4\%) While the percentage of employees with (5 years or less) experience ranked the lowest of with (12.8).

A questionnaire is designed to meet the purpose of the study; it was divided into two parts: The first part: includes the demographic factors whereas the second part: includes the study independent and dependent variables.

Scoring standards of the second part of the study in the questionnaire has been divided according to Likert quintet scale:

\begin{tabular}{|l|l|l|l|l|}
\hline 1. Strongly disagree & 2. Disagree & 3. Neutral & 4. agree & 5. strongly agree \\
\hline
\end{tabular}

Based on the values of arithmetic averages of the study it will be treated to interpret the data as follows:

1.00-2.33 low; from the 2.34-3.67 moderately: From 3.45-5.00 high degree

The stability of the study tool has been verified using two ways:

First: stability consistency: consistency is calculated using a (Test Retest). The questionnaire was applied on a sample survey of (30) individuals which were selected from within the community of the study and the outside of its sample, their degrees were monitored and the scale was benchmark on the exploratory sample itself after two weeks of the first application, monitor their grades, and calculating Pearson correlation between the two application, and table 5 shows that.

Second: reliability of the internal consistency: consistency was calculated using Cronbach's alpha, by applying it to members of the sample in the first application, and table 5 shows that.

Table 5. Transactional consistency of the study tool

\begin{tabular}{|l|l|l|}
\hline Dimension & repeated consistency & Cronbach's alpha \\
\hline Training & 0.85 & 0.83 \\
\hline $\begin{array}{l}\text { Dissemination of knowledge in the } \\
\text { company }\end{array}$ & 0.87 & 0.86 \\
\hline Select and adjust expectations & 0.85 & 0.86 \\
\hline Total & 0.90 & 0.92 \\
\hline $\begin{array}{l}\text { Application of ERP management } \\
\text { system }\end{array}$ & 0.90 & 0.89 \\
\hline
\end{tabular}

As shown in table (5) the study tool has high consistency between (85-90\%) for all dimensions, total and the dependent variable. The internal consistency measured by Cronbach's alpha ranged between $(83-92 \%)$ for all dimensions and total and for the dependent variable. 


\section{Analysis and presentation of results}

Table 6. Arithmetic means and standard deviations of sample study individual answers to training paragraphs dimension and the dimension as a whole.

\begin{tabular}{|l|l|l|l|l|l|}
\hline No. & Paragraph & $\begin{array}{l}\text { Arithmetic } \\
\text { Mean }\end{array}$ & S.D & Rank & Degree \\
\hline 1 & $\begin{array}{l}\text { it is necessary to attend a training course on } \\
\text { any new project in company }\end{array}$ & 4.82 & 42 & 1 & High \\
\hline 2 & $\begin{array}{l}\text { There is a positive experience in attending } \\
\text { informal training in the company, such as the } \\
\text { training of peer. }\end{array}$ & 4.57 & 71 & 7 & High \\
\hline 3 & $\begin{array}{l}\text { Confident in the company's ability to } \\
\text { promote the skills necessary to do periodic } \\
\text { booster to achieve project objectives. }\end{array}$ & 4.68 & 63 & 4 & High \\
\hline 4 & $\begin{array}{l}\text { Training is a mean to help employees resist } \\
\text { change. }\end{array}$ & 4.62 & 73 & 6 & high \\
\hline 5 & $\begin{array}{l}\text { Training encourages staff to use and accept } \\
\text { new regulations. }\end{array}$ & 4.71 & 56 & 3 & high \\
\hline 6 & $\begin{array}{l}\text { Training is important during and after the } \\
\text { application of the new system. }\end{array}$ & 4.66 & 58 & 5 & high \\
\hline 7 & $\begin{array}{l}\text { Training offers good opportunities to help } \\
\text { users to accept change. }\end{array}$ & 4.74 & 48 & 2 & high \\
\hline & Total & 4.69 & 42 & high & \\
\hline
\end{tabular}

As indicated in the table (6) that the total arithmetic mean came with a high degree (4.69) arithmetic mean and (0.42) standard deviation indicating that the extent and efficiency of staff to use the Enterprise resource planning system (ERP) in the Jordan Bromine Company was high.

Paragraph (1) which states "it is necessary to attend a training course on any new project in company" ranks first in high degree with (4.82) arithmetic mean and (0.42) standard deviation, this shows the importance of training in the application of a new system in the company, while paragraph number (2) which States that" there is a positive experience in informal training in the company, such as peer training "has the last place with (4.57) arithmetic mean and (0.71) standard deviation which indicates that the company relies on formal training more than informal training. 


\section{Ml Macrothink}

Journal of Management Research

ISSN 1941-899X

2014, Vol. 6, No. 4

Table 7. Arithmetic means and standard deviations of individual in the study sample answers to paragraphs dimension the dissemination of knowledge in the company and the whole dimension

\begin{tabular}{|l|l|l|l|l|l|}
\hline No. & Paragraph & $\begin{array}{l}\text { Arithmetic } \\
\text { Mean }\end{array}$ & S.D & Rank & Degree \\
\hline 8 & $\begin{array}{l}\text { knowledge management is the ability of the } \\
\text { Organization and staff to act in a meaningful } \\
\text { way towards goals }\end{array}$ & 4.65 & .51 & 3 & high \\
\hline 9 & $\begin{array}{l}\text { training, and direct guidance from the manger } \\
\text { are the sources of knowledge }\end{array}$ & 4.46 & .76 & 7 & high \\
\hline 10 & $\begin{array}{l}\text { using the new system helps to spread } \\
\text { knowledge and share data better }\end{array}$ & 4.62 & .55 & 4 & high \\
\hline 11 & $\begin{array}{l}\text { the formation of knowledge is the first step to } \\
\text { effective change management }\end{array}$ & 4.55 & .64 & 6 & high \\
\hline 12 & $\begin{array}{l}\text { the Department works to disseminate } \\
\text { knowledge to reduce staff resistance when } \\
\text { applying a new system }\end{array}$ & 4.56 & .71 & 5 & high \\
\hline 13 & $\begin{array}{l}\text { the process of publication and dissemination of } \\
\text { knowledge is one of the factors of change } \\
\text { management }\end{array}$ & 4.66 & .49 & 2 & high \\
\hline 14 & $\begin{array}{l}\text { there are internal network would that enable } \\
\text { me to share knowledge with others }\end{array}$ & 4.68 & .55 & 1 & high \\
\hline 15 & $\begin{array}{l}\text { I get adequate information about Enterprise } \\
\text { resource planning system (ERP) }\end{array}$ & 4.39 & .83 & 8 & high \\
\hline 16 & \begin{tabular}{l} 
Total \\
\hline
\end{tabular} & 4.57 & .45 & high & \\
\hline
\end{tabular}

As indicated in the table (7) that the total arithmetic mean came high with (4.57) arithmetic mean and (0.45) standard deviation, which indicates that the extent of understanding and awareness of the importance of the application of the Enterprise resource planning system (ERP) in the Jordan Bromine Company was high.

Paragraph (14), which states that " there are internal network would that enable me to share knowledge with others " came in the first place with (4.68) high arithmetic mean and (0.55) standard deviation indicating that the company possesses an effective network that enables employees to exchange knowledge among each other. Paragraph (15), which states "I get adequate information about Enterprise resource planning system (ERP) " with (4.39) arithmetic standard (0.83) standard deviation which indicates that staff were unable to obtain information on the Enterprise resource planning system (ERP). 
Table 8. Arithmetic mean and standard deviations of individual study sample answers to adjust and identify expectations and to the overall dimension

\begin{tabular}{|l|l|l|l|l|l|}
\hline No. & Paragraph & $\begin{array}{l}\text { Arithmetic } \\
\text { Mean }\end{array}$ & S.D & Rank & Degree \\
\hline 16 & $\begin{array}{l}\text { the company would be able to deal with any } \\
\text { future changes }\end{array}$ & 4.65 & .53 & 1 & high \\
\hline 17 & $\begin{array}{l}\text { change management help the Organization to } \\
\text { adapt to the surrounding environment and } \\
\text { help them to grow and survive }\end{array}$ & 4.46 & .60 & 2 & high \\
\hline 18 & $\begin{array}{l}\text { the results of the actual application is similar } \\
\text { to the expected results }\end{array}$ & 4.31 & .73 & 4 & high \\
\hline 19 & $\begin{array}{l}\text { Enterprise resource planning system } \\
\text { (ERP).help to explore unanticipated } \\
\text { investment and opportunities }\end{array}$ & 4.31 & .75 & 3 & high \\
\hline 20 & $\begin{array}{l}\text { Enterprise resource planning system (ERP) } \\
\text { can avoid various environmental threats }\end{array}$ & 4.30 & .71 & 5 & high \\
\hline 21 & $\begin{array}{l}\text { Enterprise resource planning system (ERP) } \\
\text { has the ability to create a balance between the } \\
\text { capacity of the company and the external } \\
\text { variables }\end{array}$ & 4.26 & .83 & 6 & high \\
\hline & Total & 4.38 & 54 & high & \\
\hline
\end{tabular}

As indicated in the table (8) that the total arithmetic mean came high with (4.38) arithmetic mean and $(0.54)$ standard deviation, which indicates that that the compatibility of forecasts with the actual application of the Enterprise resource planning system (ERP) in the Jordan Bromine Company was high.

Paragraph (16), which states that "the company would be able to deal with any future changes" came high in the first place with (4.65) arithmetic mean and (0.53) standard deviation this indicates the company's ability to deal with the changes in the external environment. Paragraph (21), which states "resource Enterprise resource planning system (ERP) has the ability to create a balance between the capacity of the company and the external variables" with (4.26) arithmetic standard (0.83) standard deviation this shows the inability of the system to balance the internal environment and external environment.

Before applying regression analysis to test the main hypotheses of the study "There is no statistically significant effect to apply change management according to dimensions (training, dissemination of knowledge, identify and adjust expectations) in the effective application of the system." Multi-Collinearity, Variance Inflation Factor-VIF and Tolerance tests have been made to ensure the suitability of the data for the assumptions of regression analysis. 
Table 9. Variance Inflation Factor-VIF, Tolerance and skewness

\begin{tabular}{|l|l|l|l|}
\hline Variables & Tolerance & (VIF) & Skewness \\
\hline Training & 0.614 & 1.629 & -0.784 \\
\hline knowledge dissemination & 0.473 & 2.113 & -0.965 \\
\hline Identify and adjust expectations & 0.629 & 1.590 & -0.699 \\
\hline
\end{tabular}

Table (9) which contains the independent variables and the coefficient value of the (VIF) and the "Tolerance" for each variable shows that the value of (VIF) for all variables were less than (10) and range between (1.590-2.113) as the value of the "Tolerance" for all variables were greater $(0.05)$, between $(0.473-0.629)$ therefore it can be argued that there is a real problem concerning the high correlation between independent variables. And for the investigation of Normal Distribution data it were based on a calculation of the value of (Skewness) for variables, as indicated in the table (9) the torsion coefficient value for all variables studied were lower than (1) it can therefore be argued that there is no real problem for normal distribution of data.

Table 10. Results of the (Analysis of Variance) to ensure the validity of the form to test the study hypotheses

\begin{tabular}{|c|c|c|c|c|c|c|c|}
\hline $\begin{array}{l}\text { Dependent } \\
\text { variable }\end{array}$ & Source & $\mathrm{R}^{2}$ & $\begin{array}{l}\text { Squares } \\
\text { sum }\end{array}$ & $\begin{array}{l}\text { freedom } \\
\text { degrees }\end{array}$ & $\begin{array}{l}\text { Square } \\
\text { average }\end{array}$ & $\begin{array}{l}\text { calculated } \\
\text { F value }\end{array}$ & $\begin{array}{l}\text { indications } \\
\text { level }\end{array}$ \\
\hline \multirow{4}{*}{$\begin{array}{l}\text { Effective } \\
\text { application } \\
\text { of the } \\
\text { system }\end{array}$} & Regression & \multirow{4}{*}{0.714} & 1203.845 & 3 & 401.282 & 100.614 & .000 \\
\hline & & & & & & & \\
\hline & Error & & 482.587 & 121 & 3.988 & & \\
\hline & Total & & 1686.432 & 124 & & & \\
\hline
\end{tabular}

It can be seen from table 10 that the independent variables together explains $(71.4 \%)$ of the contrast in a learning organization, which demonstrates the existence of the effect of the independent variables on the dependent variable, based on the stability the form the study hypotheses can be tested using (Multiple Regression Analysis) with (f) $=100.614$, and this value is statistically significant at the level indication $(\alpha \leq 0.05)$.

To test the hypothesis 1 which states" There is no statistically significant impact of staff training on the effective application of the Enterprise resource planning system (ERP)," multiple regression analysis of the impact of training on the effective application of the Enterprise resource planning system (ERP) was used. 
Table 11. Multiple regression analysis of the impact of training on the effective application of the Enterprise resource planning system (ERP)

\begin{tabular}{|l|l|l|l|l|l|l|l|}
\hline $\begin{array}{l}\text { Dependent } \\
\text { variable }\end{array}$ & Source & $\mathrm{R}^{2}$ & $\begin{array}{l}\text { Squares } \\
\text { sum }\end{array}$ & $\begin{array}{l}\text { freedom } \\
\text { degrees }\end{array}$ & $\begin{array}{l}\text { Square } \\
\text { average }\end{array}$ & $\begin{array}{l}\text { calculated } \\
\text { F value }\end{array}$ & $\begin{array}{l}\text { indications } \\
\text { level }\end{array}$ \\
\hline $\begin{array}{l}\text { Effective } \\
\text { application } \\
\text { of } \begin{array}{l}\text { of } \\
\text { system }\end{array}\end{array}$ & Regression & Error & 172.170 & 1 & 172.170 & 13.985 & .000 \\
\cline { 4 - 9 } & Total & 0.102 & 1514.262 & 123 & 12.311 & & \\
\cline { 5 - 8 } & & 1686.432 & 124 & & & \\
\hline
\end{tabular}

It can be seen from table (11) the effect of staff training on the effective application of the Enterprise resource planning system (ERP), explaining the training influence dimension with $(10.2 \%)$ of the effectiveness of the application of the Enterprise resource planning system (ERP), the value (f) $=13.985$, and this value is statistically significant at the level of significance $(\alpha \leq 0.05)$, and accordingly zero hypothesis is rejected, the alternative hypothesis is accepted because there is a statistically significant effect of the impact of training on the effective application of the Enterprise resource planning system (ERP).

Table 12. The values of the regression coefficients for the effect of staff training on the effective application of the Enterprise resource planning system (ERP)

\begin{tabular}{|c|c|c|c|c|c|c|}
\hline \multicolumn{2}{|c|}{ The source of variance } & B & $\begin{array}{c}\text { standard } \\
\text { error }\end{array}$ & Beta & (t) value & $\begin{array}{l}\text { level of } \\
\text { indication }\end{array}$ \\
\hline \multirow{2}{*}{$\begin{array}{l}\text { The } \\
\text { effectiveness of } \\
\text { the system } \\
\text { application }\end{array}$} & constant & 17.669 & 3.549 & & 4.979 & 000 \\
\hline & $\begin{array}{l}\text { Training } \\
\text { employee }\end{array}$ & 403 & .108 & .320 & 3.740 & 000 \\
\hline
\end{tabular}

To test the hypothesis 2 which states "There was no statistically significant effect of disseminating knowledge between staff on the effective application of the Enterprise resource planning system (ERP), multiple regression analysis was used.

Table 13. Multiple regression analysis of the impact of the dissemination of knowledge on the effectiveness of the application of the Enterprise resource planning system (ERP)

\begin{tabular}{|c|c|c|c|c|c|c|c|}
\hline $\begin{array}{l}\text { Dependent } \\
\text { variable }\end{array}$ & Source & $\mathrm{R}^{2}$ & $\begin{array}{l}\text { Squares } \\
\text { sum }\end{array}$ & $\begin{array}{l}\text { freedom } \\
\text { degrees }\end{array}$ & $\begin{array}{l}\text { Square } \\
\text { average }\end{array}$ & $\begin{array}{l}\text { calculated } \\
\text { F value }\end{array}$ & $\begin{array}{l}\text { indications } \\
\text { level }\end{array}$ \\
\hline \multirow{3}{*}{$\begin{array}{l}\text { Effective } \\
\text { application } \\
\text { of the } \\
\text { system }\end{array}$} & Regression & \multirow{3}{*}{0.330} & 556.008 & 1 & 556.008 & 60.499 & $.000^{\mathrm{a}}$ \\
\hline & Error & & 1130.424 & 123 & 9.190 & & \\
\hline & Total & & 1686.432 & 124 & & & \\
\hline
\end{tabular}

It can be seen from table (13) the effect of staff training on the effective application of the Enterprise resource planning system (ERP), explaining the training influence dimension with $(33 \%)$ of the effectiveness of the application of the Enterprise resource planning system (ERP), the value $(f)=60.499$, and this value is statistically significant at the level of significance $(\alpha \leq$ 
0.05 ), and accordingly zero hypothesis is rejected, the alternative hypothesis is accepted because there is a statistically significant effect of the impact of training on the effective application of the Enterprise resource planning system (ERP).

Table 14. The values of the regression coefficients for the effect of disseminating knowledge on effective application of the Enterprise resource planning system (ERP)

\begin{tabular}{|c|c|c|c|c|c|c|}
\hline \multicolumn{2}{|c|}{ The source of variance } & B & $\begin{array}{c}\text { standard } \\
\text { error }\end{array}$ & Beta & (t) value & $\begin{array}{c}\text { level of } \\
\text { indication }\end{array}$ \\
\hline \multirow{2}{*}{$\begin{array}{c}\text { The } \\
\text { effectiveness } \\
\text { of the system } \\
\text { application }\end{array}$} & constant & 9.595 & 2.751 & & 3.488 & .001 \\
\cline { 2 - 7 } & $\begin{array}{c}\text { Training } \\
\text { employee }\end{array}$ & .582 & .075 & .574 & 7.778 & .000 \\
\hline
\end{tabular}

To test the hypothesis 3 which states" There was no statistically significant effect to determine and adjust expectations for effective application of the Enterprise resource planning system (ERP) ", multiple regression analysis was used.

Table 15. Multiple regression analysis of the impact of setting and adjusting expectations on the effective application of the Enterprise resource planning system (ERP)

\begin{tabular}{|c|c|c|c|c|c|c|c|}
\hline $\begin{array}{l}\text { Dependent } \\
\text { variable }\end{array}$ & Source & $\mathrm{R}^{2}$ & $\begin{array}{l}\text { Squares } \\
\text { sum }\end{array}$ & $\begin{array}{l}\text { freedom } \\
\text { degrees }\end{array}$ & $\begin{array}{l}\text { Square } \\
\text { average }\end{array}$ & $\begin{array}{l}\text { calculated } \\
\text { F value }\end{array}$ & $\begin{array}{l}\text { indications } \\
\text { level }\end{array}$ \\
\hline \multirow{3}{*}{$\begin{array}{l}\text { Effective } \\
\text { application } \\
\text { of the } \\
\text { system }\end{array}$} & Regression & \multirow{3}{*}{0.698} & 1176.839 & 1 & 1176.839 & 284.053 & .000 \\
\hline & Error & & 509.593 & 123 & 4.143 & & \\
\hline & Total & & 1686.432 & 124 & & & \\
\hline
\end{tabular}

It can be seen from table (15) the effect of setting and adjusting expectations on the effective application of the Enterprise resource planning system (ERP), explaining setting and adjusting expectations dimension with (69.8\%) of the effectiveness of the application of the Enterprise resource planning system $(E R P)$, the value $(f)=284.053$, and this value is statistically significant at the level of significance $(\alpha \leq 0.05)$, and accordingly zero hypothesis is rejected, the alternative hypothesis is accepted because there is a statistically significant effect of the impact of training on the effective application of the Enterprise resource planning system (ERP) 
Table 16. The values of the regression coefficients for the effect of setting and adjusting expectations on the effective application of the Enterprise resource planning system (ERP)

\begin{tabular}{|c|c|c|c|c|c|c|}
\hline \multicolumn{2}{|c|}{ The source of variance } & B & $\begin{array}{c}\text { standard } \\
\text { error }\end{array}$ & Beta & (t) value & $\begin{array}{l}\text { level of } \\
\text { indication }\end{array}$ \\
\hline \multirow{2}{*}{$\begin{array}{l}\text { The } \\
\text { effectiveness } \\
\text { of the system } \\
\text { application }\end{array}$} & Constant & 5.772 & 1.501 & & 3.845 & .000 \\
\hline & $\begin{array}{c}\text { Set and } \\
\text { adjust } \\
\text { expectations }\end{array}$ & .955 & .057 & .835 & 16.854 & .000 \\
\hline
\end{tabular}

\section{Discussion of findings and recommendations}

The results indicated a statistically significant effect for staff training on the effective application of the Enterprise resource planning system (ERP), and this could be due to that training is an essential process in any organization, Enterprise resource planning system (ERP) needs a trained staff, so training is one of the most important factors of the Department to raise the performance levels of employees, in order for the planning to be successful staff must be trained.

The results indicated a statistically significant effect of disseminating knowledge between staff on the effective application of the Enterprise resource planning system (ERP), and this may be attributed to the spread of knowledge helps to accept employees when the company implemented a new system, and assist the employee to obtain information about the Enterprise resource planning system (ERP), and his connect with others to share knowledge leads to effective application of the system.

The results indicated a statistically significant effect of identification and adjustment of expectations for effective application of the Enterprise resource planning system (ERP), and the reason for this may be due to the individual success in his ability to predict and detect the external environment, and determine their wishes regarding Enterprise resource planning system (ERP), thus achieving the desired objectives, and in line with expectations, and benefiting from the external opportunities commensurate with the achievement of the goals.

\section{Recommendations}

In the light of the results of the study the researcher recommends the following:

1. The company should be more interested in training, as it plays a role in change management, and reflected on the effective application of Enterprise resource planning system (ERP) in the company, through the provision of training courses for company projects.

2. The company should provide evidence to helps employees to get the necessary information on Enterprise resource planning system (ERP), and inform them of all new information about it, by holding lectures. 


\section{$\triangle$ Macrothink}

3. Creating a section for public relations to provide promotion campaigns and awareness about Enterprise resource planning system (ERP).

4. Senior management should examine the structure and needs of the users and possible reasons for resistance, and deal with the situation by using strategies and techniques appropriate for introduction of Enterprise resource planning system (ERP)

5. Propose strategies of change management to determine the objectives and quality standards.

6. Coordination of plans and activities to achieve the objectives of the company and identify strengths and weaknesses faced by the company.

7. Motivating all levels of management to work together to accomplish the change process.

8. Encourage innovations and initiatives that contribute to the process of change and urged employees and motivate them to use creativity and challenge in the company.

9. The company should seek to achieve organizational loyalty in people and achieve job satisfaction through integrity and transparency in the work reward creators and improve functional status.

\section{References}

Abodi ,Zaid. (2006). management of change and development, the treasure house of knowledge of publishing and distribution, Amman, Jordan.

Al nafjan, Abeer and Almodmaj, Abudallah. (2005). the impact of the change management system resource management and planning. technology information theoretical and applied journal, 91-97, Riyadh, Saudi Arabia.

Al nafjan, Abeer and Almodomaj, Abdullah. (2005). The impact of the change management system resource management and planning. Journal of theoretical and applied information technology, 91-97, Riyadh, Saudi Arabia.

Albali, Hala (2011). Strategies for effective change management and ERP management systems. International Journal of computer applications, 17(2), 14-19, Riyadh, Saudi Arabia.

Alfarisi, Khadija. (2006). The impact of human resource management functions in achieving organizational change in central ministries in the Sultanate of Oman, Master thesis, University of Jordan, Amman, Jordan.

Algilani, Salah. (2005).change management in the Ministry of education and learning in the Sultanate of Oman from the point of view of the employees. Master thesis, Yarmouk University, Irbid, Jordan.

Alideanie, Adel. (2001). change management strategy for the successful application of ERP management system. Business management magazine, 7(3), Kuwait.

Almriat, Amal. (2008). Building educational strategy proposed for the management of change in southern Jordan. master, Yarmouk University, Irbid, Jordan. 
Al-Salmi Ala' Abdel Razzak. (1999). Information systems and artificial intelligence, first edition, publication and distribution of curricula, Amman.

Alshamlan, Hala, \& Almdmth, Abdullah. (2011). Change management strategies and operations management system and resource planning: a case study of orbit. International Conference on communications, computers, 7, Riyadh, Saudi Arabia.

Al-Taie, \& Mohammed Abdel Hussein. (1995). The impact of the regulatory climate in the indicators of the effectiveness of management information system. unpublished $\mathrm{PhD}$ thesis, Faculty of Economics, University of Mosul.

Al-Titi, Kader. (2010). change management, Dar al-Hamed for publishing and distribution, Amman

Ameri, Fadel Abbas Jassem. (1998). The role of MIS in identifying strategic choice", unpublished Ph.d. thesis, Faculty of management and economics, Mustansiriyah University.

Andreas Nicolaou. \& Somnath Bhattacharya. (2006). Organizational performance effects of ERP systems usage:

Atiyyah, Hamid S. (1989). Determinants of computer system effectiveness in Saudi Arabian public organization. Int. Studies of Mgt. \& Org., 19(2), 85-103.

Bernhard Wieder, \& Peter Booth. (2006). The impact of ERP systems on firm and business process performance. Journal of Enterprise Information Management, 19(1), 13-29. http://dx.doi.org/10.1108/17410390610636850

Bryson, W. (1990). Information systems. N.L Prentice-Hall.

Burns, Justyna, \& Madey, Gregory. (2001). A frame work for effectiveness user interface design for web-based electronic commerce applications. Infromation science, 4(2), 67-75.

Daft, R.L. (2001). Organization theory and design. 7th ed,south western college publishing, Ohio.

El Serafy, Mohammad. (2008), change management, Dar Alfiker AlJmie House-Alexandria.

Hagg, Stephen., Cummings,Meave., \& McGubbrey, D.J. (2004). Management information systems for information age. 4th.Ed, McGraw-Hill.

Hamilton, Scott., \& Chervancy, Norman L. (1981). Evaluating information system effectiveness part II: Comparing evaluator view point. MIS Quarterly, December, 79-86.

Hamilton,Scott., \& Chervancy, Norman L. (1981). Evaluating information system effectiveness part II: Comparing evaluator viewpoint. MIS Quarterly, December, 79-86.

Hammer, Chiampi. (1995). Re-engineering work systems in organizations "reengineering", publication of the Arabic scientific information company "Ray", Cairo. 


\section{Macrothink}

Journal of Management Research ISSN 1941-899X 2014, Vol. 6, No. 4

Harem, Hassan. (2006). The impact of the management of organizational change in resistance to change: a field study in chemical companies. Irbid for the research and study, 10(1), Irbid, Jordan.

Hicks, Jr. James, O. (1990). Information systems in business: an introduction. 5th. Ed,west publishing company.

Husayniyah, Saleem. (1998). Principles of management information systems. first edition, Alwarak for publishing and distribution, Amman, Jordan.

Kim. K.Kyu. (1989). User satisfaction: A synthesis of three different perspective. Journal of information Technology Fall, 1-120

krasnh, Abdel Fattah Alkalili, somiah. (2009). Knowledge management components: analytical study on the Jordanian Ministry of education. Jordan business magazine, 5(3), Amman, Jordan.

Munshi Jamal. (2004). A framework for MIS effectiveness.

OZ. Effy. (2000). Management information systems, 2nd.Ed, Course Technology A division of thomason learning.

Palanisamy, Ramaraj., \& Sushil. (2001). Empirically testing the relationship between user involvement,information waste, and MiS Success. Journal of services Research, 10(1), 70-103.

Sabbagh Imad. (2005). ERTT in the digital environment: the basics of change management. Sharjah University Journal of science, humanity, 2(1), Soor, Sultanate of Oman.

Sadagopan. S. (1998). Management information systems. Prentice, Hall of India private limited,New Delhi.

Shahin, Sherif Kamel. (1994). Management information systems of libraries and information centres: concepts and applications. Mars for publication, Riyadh.

Tal'at Asaad Abdul Hamid. (1992). Management of administrative systems, library University of Helwan, Cairo

The impact of post-implementation changes. International Journal of Accounting Information Systems, 7(1) 18-35. http://dx.doi.org/10.1016/j.accinf.2005.12.002

Wikipedia. (2003). Knowledge management, available under the terms of the GUN Free Documentation License, 27 Sep.

Yaghi, Mohammad. (2003). Theoretical training and Application Center, Ahmed Yassin, Amman, Jordan.

Zabieb, Imad Ahmed, Zafar (2006). Resistance management and the application of management system and resource planning. Asian academic administration magazine, 11(2), 1-17, Beirut, Lebanon. 
Zwass, Vladimir. (1994). Management Information systems, 17. WM.C.Brown publisher USA. http://www.islamtoday.net/articles/show_articles_content.cfm?id=177\&cati $\mathrm{d}=100 \& \operatorname{artid}=54$ 